\title{
In vitro studies of the anthelmintic activity of Picrolemma sprucei Hook. f. (Simaroubaceae)
}

Rita de Cássia Saraiva NUNOMURA ${ }^{2,3}$, Ellen Cristina Costa da SILVA ${ }^{2,3}$, Denilson Ferreira OLIVEIRA ${ }^{4}$, Adriana Mello GARCIA ${ }^{5}$, Jankerle Neves BOELONI 5 , Sergio Massayoshi NUNOMURA ${ }^{6}$, Adrian Martin POHLIT ${ }^{2,6}$

\section{ABSTRACT}

$1300 \mathrm{ppm}(1.3 \mathrm{~g} / \mathrm{L})$, water and ethanol extracts prepared from stems or roots of Picrolemma sprucei Hook. f. were lethal (85-90\% mortality) in vitro to Haemonchus contortus (Barber Pole Worm) larvae, a gastrointestinal nematode parasite found in domestic and wild ruminants. Neosergeolide and isobrucein B were isolated in 0.0083 and $0.0070 \%$ yield from dry, ground P. sprucei stems $(0.89 \mathrm{~kg})$. Neosergeolide, isobrucein B and the anthelmintic drug standard levamisole all caused comparable mortality rates (68-77 $\%)$ in vitro to $H$. contortus at similar concentrations ( $81-86 \mathrm{ppm}$ ). The anthelmintic activity of $P$. sprucei infusions (teas), alcohol extracts, and neosergeolide and isobrucein $\mathrm{B}$, has therefore been demonstrated for the first time.

\section{KEYWORDS}

Picrolemma pseudocoffea Ducke, Haemonchus contortus, neosergeolide, isobrucein B, caferana.

\section{Estudos in vitro da atividade anti-helmintica de Picrolemma sprucei Hook.f. (Simaroubaceae)}

\begin{abstract}
RESUMO
Na concentração de 1300 ppm $(1.3 \mathrm{~g} / \mathrm{L})$, extratos aquosos e etanólicos preparados a partir dos caules ou raizes de Picrolemma sprucei Hook. f. apresentaram letalidade (85-90\% de mortalidade) in vitro para Haemonchus contortus, um nematóide parasitico do aparelho gastrointestinal de ruminantes domesticos e silvestres. Neosergeolida e isobruceina B foram isoladas dos caules em rendimentos de 0.0083 and $0.0070 \%$, respectivamente. Essas ültimas a a droga anti-helmintica levamisole provocaram mortalidade semelhante in vitro (68-77\%) em H. contortus em concentraçōes semelhantes (81-86 ppm). A atividade anti-helmintica in vitro de infusōes e extratos alcoólicos dos caules, bem como da neosergeolida e isobruceina B isoladas de P. sprucei, foi demonstrada pela primeira vez.
\end{abstract}

\section{PALAVRAS-CHAVE}

Picrolemma pseudocoffea Ducke, Haemonchus contortus, neosergeolida, isobruceina, caferana.

\footnotetext{
${ }^{1}$ Part of the work herein was described in the Master's Dissertation by Saraiva (2001).

${ }^{2}$ Departamento de Química, ${ }^{3}$ Curso de Pós-graduação em Química de Produtos Naturais, Instituto de Ciências Exatas, Universidade Federal do Amazonas (UFAM), Avenida General Rodrigo Otávio Jordão Ramos, 3000, Aleixo Campus Universitário, 69.077-000, Manaus, Amazonas, Brazil.

${ }^{4}$ Departamento de Química, ${ }^{5}$ Departamento de Medicina Veterinária, Universidade Federal de Lavras, Caixa Postal 37, 37.200-000, Lavras, Minas Gerais, Brazil.

${ }^{6}$ Coordenação de Pesquisas em Produtos Naturais (CPPN), Instituto Nacional de Pesquisas da Amazônia (INPA), Avenida André Araújo, 2936, Petrópolis, 69083-000, Manaus (telefone/FAX92 3643-3177, ampohlit@inpa.gov.br).
} 


\section{INTRODUCTION}

Parasitoses have been of concern to the medical field for centuries and the helminths still cause considerable problems for human beings and animals. During the past few decades, despite numerous advances made in understanding the mode of transmission and the treatment of these parasites, there are still no efficient products to control certain helminths and the indiscriminate use of some drugs has generated several cases of resistance (Coles, 1999; Geerts \& Gryseels, 2000; Sangster, 1999). Furthermore, it has been recognized recently that anthelmintic substances having considerable toxicity to human beings are present in foods derived from livestock, posing a serious threat to human health (Padilha, 1996; Turnipseed et al., 1999). Consequently, the discovery and development of new chemical substances for helminth control is greatly needed and has promoted studies of traditionally used anthelmintic plants, which are generally considered to be very important sources of bioactive substances (Hamond et al., 1997).

Picrolemma sprucei Hook. f. (syn. P. pseudocoffea Ducke) is a small tree or low shrub which is native to and widely distributed in the Amazon region. It is used against worms in Peru (Duke \& Vasquez, 1994), French Guyana (Grenand et al., 1987) and Brazil (Le Cointe, 1947). In the Brazilian Amazon, this plant is known by the popular name caferana. Remedies are prepared by maceration of a few stem bark shavings in a small amount of rum or by infusion of the whole plant.

The isolation of quassinoid compounds isobrucein $\mathrm{B}$ and neosergeolide (Figure 1) from P. sprucei has been described previously by Moretti et al. (1982) and Vieira et al. (2000), respectively, and their presence in stem and root hot water infusions of this plant has been established using high performance liquid chromatography (Saraiva, 2001).

The objective of this work was to explore the anthelmintic properties of P. sprucei extracts, as well as the isolated quassinoid compounds isobrucein B and neosergeolide, in Haemonchus contortus, a gastrointestinal nematode found in sheep and other animals. To our knowledge, the anthelmintic activity of P. sprucei, isobrucein $\mathrm{B}$ and neosergeolide has not been previously demonstrated.

\section{MATERIAL AND METHOD}

Plant Materials. Collection was performed on the UFAM campus in Manaus during the period July, 1998 to January, 1999. Voucher specimens were deposited at the UFAM Herbarium (Silva $5729 \& 5730$ ) and identified as Picrolemma sprucei Hook. f. by Dr. Wayt Thomas.

Preparation of Water Extracts. Powdered root and stem (9.0 g) were infused in boiling, de-ionized water $(1.0 \mathrm{~L})$ for $10 \mathrm{~min}$, followed by hot filtration and total evaporation, providing extract in 2.5 and $5 \%$ yield, respectively.

Preparation of Ethanol Extracts. Powdered root (30-150 g) and stem $(5-40 \mathrm{~g})$ were extracted with ethanol three times using the sequence: ultrasonication (30 min), maceration (2 weeks) and filtration. The filtrates were combined and totally evaporated. Extract yields averaged about $6 \%(\mathrm{w} / \mathrm{w})$ for roots and $10 \%$ for stems.

Isolation and Identification of Quassinoids. The procedure utilized for the isolation of quassinoid compounds was essentially that previously described by Moretti et al. (1982). Briefly, this consisted of degreasing (by maceration in hexanes), then exhaustive hot water extraction of powdered stems $(0.89 \mathrm{~kg})$, followed by continuous liquid-liquid extraction of the resulting concentrated water extract with chloroform. Neosergeolide (73.9 $\mathrm{mg})$ and isobrucein B $(62.0 \mathrm{mg})$ were isolated by sequential column chromatography (silica gel) on the chloroform fraction $(10.8 \mathrm{~g})$, followed by recrystallization (Saraiva, 2001). Identification of these compounds was performed by comparison of physical and spectral data for these compounds with literature data (Moretti et al., 1982; Vieira et al., 2000).

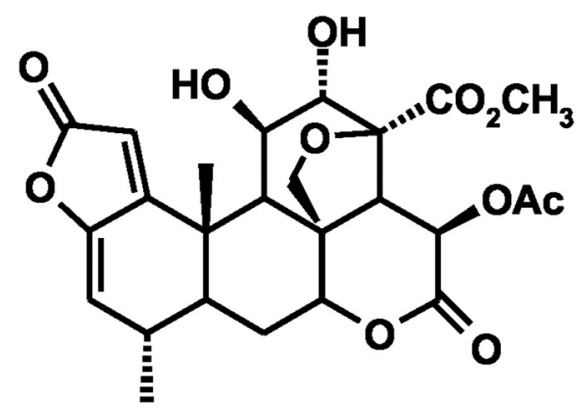

neosergeolide

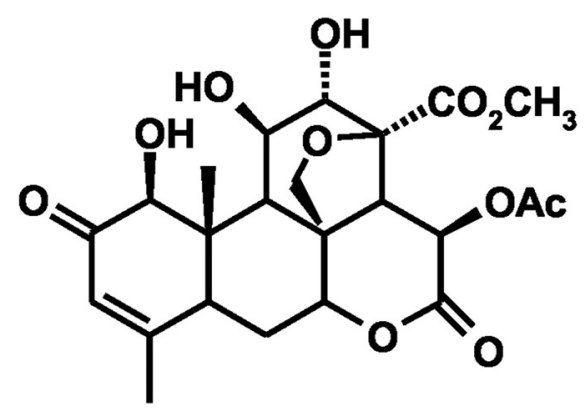

isobrucein B

Figure1 - Structures of quassinoids found in the roots and stems of $P$. sprucei. 
Cultivation of Larvae. Fresh dung from a single sheep infected with Haemonchus contortus was collected in a holding bag. Water and vermiculite were added and the mixture was incubated (27 ${ }^{\circ} \mathrm{C}$, 1 week). Next, infectious $H$. contortus larvae (L3) were separated from other materials using the Baermann technique (Tihohod, 1993) which resulted in an L3 suspension in water. All suspensions had $>95 \%$ live L 3 before use.

Evaluation of the Anthelmintic Activity of Isolated Quassinoids and Extracts. Test solutions $(300 \mathrm{~mL})$, prepared by dissolving extract or substance in aqueous $1 \%$ Tween 80 , and a suspension $(50 \mathrm{~mL})$ containing $50 \mathrm{~L} 3$ were placed in wells $(400 \mathrm{~mL})$ on a multi-well test plate. Water $(300 \mathrm{~mL})$ and $1 \%$ Tween 80 were used as negative controls and aqueous levamisole phosphate $(300 \mathrm{~mL})$ as positive control (Igbal et al., 2005; Table 1). Experiments and controls were performed using five repetitions. After $24 \mathrm{~h}$ at room temperature, the dead and viable larvae were counted using a microscope with inverted lens. Mortality (M $\%)$ of $\mathrm{L} 3$ after $24 \mathrm{~h}$ was evaluated as a percentage: $\mathrm{M}(\%)=100$ ' Dead L3 / (Live L3 at $\mathrm{t}_{0}$ ). Variance analysis (ANOVA) was performed and means were separated using the Scott-Knott test ( $P$ 0.05). Statistical analyses were performed using SISVAR software.

\section{RESULT AND DISCUSSION}

Water and ethanol extracts of both roots and stems presented similar lethality towards L3 at $1.3 \mathrm{mg} / \mathrm{mL}$ (Table 1), killing almost all larvae (85-90 \%) in the test wells. It is noteworthy that our stem and root water extracts were prepared using extraction methods (infusion, $10 \mathrm{~min}$ ) and quantities (1-9 g dry, crushed stem / L boiling water) which are often the basis for remedies suggested by raizeiros ${ }^{1}$ in Amazonas State for fevers and malaria (no anthelmintic recipe is known to us). Based on the percent yields of dry extract obtained, the stem and root teas prepared in this study should be considered to have non-volatile solute concentrations of $c a .225$ and $450 \mathrm{ppm}$, respectively (Saraiva, 2001), or approximately $1 / 6$ to $1 / 3$ the extract test concentrations that were effective at killing $H$. contortus in vitro.

As can be seen from the data presented in Table 1, isolated quassinoids neosergeolide and isobrucein $\mathrm{B}$, were very active in vitro in L3, producing mortality similar to levamisole (a commonly employed drug for the treatment of intestinal worms in veterinary practice) in the concentration range of 80-90 ppm. All extracts were essentially equal in activity, regardless of the plant part or solvent / extraction method used. The data presented in Table 1 demonstrate the potential anthelmintic activity of water and ethanol stem or root extracts in $H$. contortus larvae in vitro.
Further studies involving in vivo models of anthelmintic activity should permit evaluation of the potential of P. sprucei extracts, isolated quassinoids and derivatives as nematicides.

\section{ACKNOWLEDGMENTS}

This article is dedicated to Prof. Warwick Estevam Kerr, INPA's Director during the period in which this study was undertaken, whose enthusiasm for research on Amazon biodiversity has served as inspiration to the authors.

This work was supported by the National Council for Scientific and Technological Development (CNPq; Process

Table 1 - Lethality data for samples derived from Picrolemma sprucei Hook.f. to Haemonchus contortus larvae.

\begin{tabular}{|c|c|c|c|}
\hline \multicolumn{4}{|c|}{ Test Concentration* } \\
\hline Sample & $g / L$ & $\mathrm{ppm}$ & Mortality $(\%)^{\star \star}$ \\
\hline root water extract & 1.3 & 1300 & $85 \mathrm{~d}$ \\
\hline stem water extract & 1.3 & 1300 & $90 \mathrm{~d}$ \\
\hline root ethanol extract & 1.3 & 1300 & $90 \mathrm{~d}$ \\
\hline stem ethanol extract & 1.3 & 1300 & $90 \mathrm{~d}$ \\
\hline isobrucein B & 0.086 & 86 & $72 \mathrm{~b}$ \\
\hline neosergeolide & 0.086 & 86 & $77 \mathrm{c}$ \\
\hline \multicolumn{4}{|l|}{ Controls } \\
\hline levamisole & 0.081 & 81 & $68 \mathrm{~b}$ \\
\hline tween $80,1 \%$ & --- & --- & $10 \mathrm{a}$ \\
\hline water & --- & --- & $10 \mathrm{a}$ \\
\hline
\end{tabular}

${ }^{\star}$ Well concentrations. ${ }^{\star \star}$ Average of 5 repetitions. The same letter beside values in this column means there exists no significant variation between them $(P £ 0.05)$.

Number 520354/99-0) and Bioamazonia (Contrato BASAFEPAD). R.C.G.S. (AP), E.C.C.S. (PIBIC / IC) and S.M.N. (DCR) thank CNPq for stipends. The help of Mr. Silo S. Silva and Ms. M. Rosalba Bilby (Herbarium / UFAM) during collection and identification of plant material is gladly recognized. The authors also thank Dr. Wayt Thomas of the New York Botanical Gardens (U.S.A) for help with botanic identification.

\section{LITERATURE CITED}

Coles, G.C. 1999. Anthelmintic resistance and the control of worms. JMed. Microb., 48: 323-325.

Duke, J.A.; Vasquez, R. 1994. Amazonian Ethnobotanical Dictionary. CRC Press, Boca Raton. 215 p.

Geerts, S.; Gryseels, B. 2000. Drug resistance in human helminths: current situation and lessons from the livestock. Clin. Microbiol. Rev., 13(2): 207-222.

${ }^{1}$ a term used in the Brazilian Amazon region for the popular venders of roots and other plant parts used for medicinal purposes. 


\section{ACTA
AMAZONICA}

IN VITRO STUDIES OF THE ANTHELMINTIC ACTIVITY OF

Picrolemma sprucei HOOK. F. (SIMAROUBACEAE)

Grenand, P.; Moretti, C.; Jacquemin, H. 1987. Pharmacopées Traditionelles en Guyane: Créoles, Palikur, Wayāpi. Orstom, Paris. $569 \mathrm{p}$.

Hamond, J.A.; Fielding, D.; Bishop, S.C. 1997. Prospects for plant anthelmintics in tropical veterinary medicine. Vet. Res. Comm. 21: 213-228.

Iqbal, Z.; Lateef, M.; Jabbar, A.; Muhammad, G.; Khan, M.N. 2005. Anthelmintic activity of Calotropis procera (Ait.) Ait. F. flowers in sheep. J Ethnopharmacol., 102(2): 256-61.

Le Cointe, P. 1947. Arvores e Plantas Úteis (Indigenas e Aclimatadas). 2nd ed. Companhia Editora Nacional, São Paulo. 506 p.

Moretti, C.; Polonsky, J.; Vuilhorgne, M.; Prange, T. 1982. Isolation and structure of sergeolide, a potent cytotoxic quassinoid from Picrolemma pseudocoffea. Tetrahedron Lett., 23(6): 647-650.

Padilha, T. 1996. Residuos de Anti-helminticos na Carne e Leite. In: Controle dos Nematóides Gastrintestinais em Ruminantes. Padilha, T., Ed., General Pacheco, Embrapa-CNPGL, 258 p.

Sangster, N.C. 1999. Anthelmintic resistance: past, present and future. Intl. J. Parasitology, 29: 115-124.
Saraiva, R.C.G. 2001. Estudo Fitoquímico de Picrolemma sprucei Hook (Simaroubaceae) e Dosagem dos Princípios Antimaláricos nos Chás do Caule e Raiz. Master's Dissertation, UFAM, Manaus. $88 \mathrm{p}$.

Tihohod, D. 1993. Nematologia Agricola Aplicada. Jaboticabal: FUNEP. 372 p.

Turnipseed, S.B.; Roybal, J.E.; Rupp, H.S.; Gonzalez, S.A.; Pfenning, A.P.; Hurlbut, J.A. 1999. Confirmation of avermectin residues in food matrices with negative-ion atmospheric pressure chemical ionization liquid chromatography / mass spectrometry. Rapid Comm.Mass Spec., 13: 493-499.

Vieira, I.J.C.; Rodrigues, E.; Fernandes, J.B.; Silva, M.F.G.F.; Vieira, P.C. 2000. Complete ${ }^{1} \mathrm{H}$ and ${ }^{13} \mathrm{C}$ chemical chift assignments of a new C22-quassinoid isolated from Picrolemma spruce $i$ Hook by NMR spectroscopy. Magn. Reson. Chem., 38: 805-808.

Recebido em 16/09/2004

Aceito em 02/05/2006 